IBAD, 2019; (Özel Sayı): 53-63

DOI: $10.21733 /$ ibad.610878

Özgün Araştırma / Original Article

\title{
Edilgen Yapıların Edinimi: Anlambilimsel Ve Edimbilimsel Yaklaşım
}

\author{
Öğr. Gör. Sercan Karakaş ${ }^{1 *}$
}

Gelis tarihi: 26.07 .2019

Kabul tarihi: 26.08 .2019

\section{Atıf bilgisi:}

IBAD Sosyal Bilimler Dergisi

Sayı: Özel Sayı Sayfa: 53-63

Yıl: 2019

This article was checked by Turnitin. Similarity Index \% 21.

1 Istanbul Aydın Üniversitesi, Türkiye, sercank@aydin.edu.tr

ORCID ID 0000-0002-1813-351X

* Sorumlu yazar
$\ddot{O Z Z}$

Bu makale, edilgen yapıların edinilmesi açısından alanyazının genel bir incelemesini sunmanın yanı sıra, edilgen yapıların temel zorluk nedenleri olduğu düşünülen anlambilimi ve edimbilimi göz önünde bulundurularak yeni bir teorik yaklaşım sunmaktadır. Alanyazında edilgen yapıların zor olup olmadığı ve eğer zor ise, bu zorluğun altında yatan nedenlerin ne olabileceği konusunda bir anlaşmazlık vardır. Alanyazında sunulan argümanlara dayanarak, sözdizimsel hipotez (Wexler 2004) ve artımlı işleme hipotezi (Trueswell ve Gleitman 2004) öne çıkmaktadır. Wexler'ın sözdizimsel hipotezi, çocukların tüm küçük eylem öbeklerini ve tümleyici öbeklerini güçlü fazlar olarak görmelerini savunur ve bunun sonucunda çocuklar edilgen yapıları dilbilgisi dışı olarak gördüklerini iddia eder ki bu da Wexler'a göre zorluğun kaynağıdır. Bununla birlikte, her iki durumda da (sözdizimsel hipotez veya artımlı işleme), bu yapıların frekansı büyük rol oynamaktadır. Bu çalışmada son olarak ise edilgen yapıların neden bazı dillerde edinilmesinin zor olduğunu açıklamak için anlambilimsel ve edimbilimsel bakış açıları temel alınarak kuramsal bir analiz sunulmaktadır çünkü alanyazındaki edilgen yapılar ile ilgili çalışmalar anlam bileșenini ihmal etmektedir. Bu çalıșmada, edilgen yapıların edinilmesine yeni teorik bir bakış açısı sağlamak için içlemsel anlambilim modeli (Von Fintel ve Heim 2011) kullanılmıştır.

Anahtar Kelimeler: Edilgen Yapılar, Kısa Edilgen Yapılar, Artımlı İşleme Hipotezi, Sözdizimsel Hipotez 


\section{Acquisition of Passives: A Semantico-Pragmatic Approach}

\section{Instructor Sercan Karakaş ${ }^{1 *}$}

First received: 26.07 .2019

Accepted: 26.08.2019

\section{Citation:}

IBAD Journal of Social Sciences Issue: Special Issue Pages: 53-63 Year: 2019

This article was checked by Turnitin. Similarity Index \% 21.

1 Istanbul Aydin University, Turkey, sercank@aydin.edu.tr

ORCID ID 0000-0002-1813-351X

$*$ Corresponding Author

\begin{abstract}
This paper presents a general review of literature in terms of acquisition of passives as well as providing new theoretical insights considering the semantics and pragmatics of passives, which are thought to be the underlying reasons of difficulty. There is a disagreement in the literature as to whether passive structures are difficult and if so, what may be the underlying causes of this difficulty. Based on the arguments presented in the literature, the syntactic hypothesis (Wexler 2004) and the incremental processing hypothesis (Trueswell and Gleitman 2004) stand out. Wexler's syntactic hypothesis is that children regard all vP's and CP's as strong phases, which makes non-grammatical passives for them, which is the source of the difficulty. In the meantime, in both cases (syntax or incremental processing), frequency plays a major role in boosting the acquisition process by either making children be faster at reassigning thematic roles, which is the source of difficulty according to incremental processing hypothesis, or making children be aware of the fact that vPs are not strong phases, thereby making passives grammatical, so that children can use them. Finally, in this study, a theoretical analysis based on semantic and pragmatical perspectives is presented to explain why passive structures are difficult to acquire in some languages because the studies on passive structures in the literature neglect the meaning component. In this study, the introspective semantics model (Von Fintel and Heim 2011) was used to provide a new theoretical perspective on the acquisition of passive structures.
\end{abstract}

Keywords: Passives, Truncated Passive, Incremental Processing Hypothesis, Syntactic Accounts for Passives 


\section{INTRODUCTION}

In the literature of acquisition of passives, passives are said to be complex structures; therefore, their acquisition also happens at a slower rate, which is also evidenced in the late use of passives by children. However, there are some counter arguments in the literature that advocate production of passives is not as late as it was previously thought to be. This is due to some other factors such as the type of passive, whether it is an experiencer-theme passive, as some studies report that children are prone to produce and comprehend some certain type of passive earlier. Alternatively, the frequency of passives in the language contributes to the early production of passives when compared to the languages in which these constructions are not that frequent. The second point I focus on in this paper is the difference in terms of full passives and truncated passives as in the literature, their acquisition is said to be different in terms of the onset of the acquisition, truncated passives being acquired earlier compared to full passives and there are some hypotheses as to why there is a difference in relation to the onset of acquisition of truncated passives and full passives. Having established that, let us look at different types of passives primarily from English and some other languages.

(1) The lamp $p_{i}$ was broken $t_{i}$ (by Sarah). Verbal Passive

(2) The lamp was green. Adjective

(3) The lamp was broken. Ambiguous (Verbal or Adjectival Passive)

(Kline and Demuth 2010)

In the first sentence, when we look at the ingredients of the verbal passive, we see that there is a movement involved, which means that the object of the sentence has moved to a higher position and become the subject of the sentence, leaving a trace behind, which is coindexed with the subject. On the other hand, we see a regular adjective use in the second sentence, which seems to be parallel to the passive structure in the third sentence. Even though the authors claim that it is ambiguous between verbal or adjectival passive types, it is worth noting that the sentence in (2) is very similar to the sentence in (3) structurally. Besides, it is possible to say a green lamp in English and interesting enough, a broken lamp can also be uttered in English. Furthermore, it is also significant to note that the biggest difference between verbal passives and adjectival passives is that the latter does not involve movement in contrast to verbal passives in English.

\subsection{Passives are difficult to acquire}

As we have seen in the English examples in the previous section, the passive structure in English involves movement of the object to the subject position, as a result of which the moved element (a-chain or argument) leaves a trace behind. Therefore, the principle which governs this type of movement, a movement from object to subject, is maturated at the age of five approximately, which is known as Achain Deficit Hypothesis (ACDH) (Borer and Wexler 1987, 1992). This hypothesis not only predicts that English-speaking children acquire structurally more complex verbal passives at the age of 5; but also, predicts that adjectival passives are acquired earlier due to the fact that they do not involve any a-chain movement syntactically. Based on this, it seems to be the case as there is a difference in terms of onsets of the acquisition of adjectival passives and verbal ones. However, this seems to be invalid after the development of new syntactic theories. To be more precise, the subject of a sentence is thought to be generated in the specifier position of a little vP, which makes the subject under negation, tense and aspect. Then, it raises to the specifier position of a TP due to Extended Projection Principle that English has and this process creates an A-chain, with which children do not seem to have a problem as they raise the subject after it being generated at a lower level (Stromswold 1996). If movement were a problem for children, then we would expect the same problem with subject-raising, too. The second hypothesis as cited in Kline and Demuth (2010) is the External Argument Requirement Hypothesis (EARH), which advocates that the lack of external arguments in the input underlie the problem for children. To be more precise, children may represent the sentence 'the vase was black' as a syntactic homophone with 'the vase was broken', which results in the fact that children treat verbal passives as being adjectival passives and that is why they do not use by-phrase in these structures. Another difference commonly found in English passive constructions is that agent-patient passives are acquired earlier when compared to 
experiencer-theme passives, which means that actional passives are acquired earlier than non-actional passives. This is illustrated below:

I washed the car.

The was washed. (referred to as actional passive)

I saw the boy.

The boy was seen. (referred to as non-actional passive)

According to the experiments and observations, passives with the second set of verbs are comprehended later than passives in the first set of verbs. This is explained by Fox and Grodzinsky (1998) who claim that early utterances of passives in children's speech are truncated passives, which lack by-phrase. The reason is that the grammar of young children is not mature enough for verbs to assign a thematic role to the noun phrase and a noun phrase without a thematic role is not licensed in the sentence; therefore, byphrase is not used. If this hypothesis is accepted, it is expected that children have problems with only byphrase rather than the verb types, whether it is an actional verb or a non-actional verb. (Messenger et al., 2012). Fox and Grodzinsky (1998) also argue that preposition by is responsible for assigning the thematic role to the noun phrase and it assigns an agentive theta-role. However, when the noun phrase is an experiencer rather than an agent, then the verb cannot assign the right theta-role, which results in the fact that children refrain from using experiencer (non-actional verbs in that sense) because of the wrong assignment of the theta-role.

\subsection{ACQUISITION OF PASSIVES: FREQUENCY EFFECT AND OVERT MORPHOLOGY}

In the literature, it is stated that especially verbal passives in English are not acquired until the age of six (Alcock et al., 2012) despite its early appearance in different languages such as Sesotho, Kiswahili and Kigiriama and Alcock et all. (2012) observe the languages, the passive structures of which are acquired earlier, in order to find some common patterns as to why there is a difference in terms of onsets of acquisition of passive constructions.

\subsection{High Frequency}

All of the three languages mentioned above have rich input in terms of passives and as proposed by Demuth (1989), the higher the frequency of such constructions is, the earlier these constructions emerge. This seems to be logical at first sight as one can expect children to learn things quicker if they are exposed to these things more. However, this does not falsify the A-chain Deficit Hypothesis (ACDH) (Borer and Wexler 1987, 1992) as it only modifies it. The reason is that the children may start using movement at an earlier age if they are exposed to movement required by passive structures more. In other words, combining A-chain Deficit Hypothesis with the effect of frequency, one can have the hypothesis of "the higher the frequency of passive constructions is, the quicker A-chain matures".

\subsection{The presence of obligatory passive constructions}

As mentioned in the introduction section, languages like Sesotho cause passive constructions to be unavoidable in certain contexts as using the active counterpart of the same sentence yields ungrammaticality. The reason is that some Bantu languages are called topic-oriented languages since there is a very strong tendency to put the topic in the subject position (Bresnan and Mchombo 1987). As wh-questions introduce new information rather than a topic, these questions cannot appear in the subject position, making a sentence like "who saw me?" in English impossible to be constructed. Such constructions are exemplified below:

Active: *Mang o-pheh-ile lijo?

who sm-cook-prf food? (who cooked the food?)

Passive: Lijo li-pheh-il-o-e mang?

food sm-cook-prf-pass-m who? (the food was cooked by who?) (Kline and Demuth 2010). 


\subsection{Passives being less cognitively demanding compared to actives}

Allen and Crago (1996) observe a crucial difference between active sentences and passive sentences in Inuktitut. This difference is that the verb has to agree with two arguments in active constructions; however, it only agrees with one argument in a passive construction as the other argument is deleted in passives, thus making passive structures easier than active counterparts in terms of syntactic operations. Interesting enough, even adults may prefer using passives for the same reason as they may think passives are more "practical". Therefore, there seems to be an important disagreement in terms of whether passives are really challenging.

\section{EXPERIMENTS \& DISCUSSION}

When it comes to the languages under investigation, Kiswahili and Kigiriama, in Alcock et all. (2012), passives are observed to have relatively high frequency and verbs in the active sentences have to agree with both arguments in a sentence under some, but not all, circumstances, whereas passive constructions only agree with one argument. Besides, passives are marked with a consistent marker. One crucial difference between Sesotho and Kiswahili and Kigiriama is that in questions asking the subject, passives have to be used in Sesotho, which is not the case in Kiswahili and Kigiriama as both actives and passives can be used in the formation of all types of questions. To test these assumptions, Alcock et al., (2012) designed an experiment in the following way: Spontaneous speech samples from 15 children in total were collected in children's houses while they were playing. Then, the samples were transcribed with the exclusion of adults speech in the samples collected. During the coding stage, the number of utterances, the number of verbal utterances, and the number of passives were recorded and coded accordingly. Verbs were also coded depending on whether they were in an active construction or in a passive structure, which were also coded as either actional or non-actional later on. Passives that were a repetition of the same verb by the same or another interlocutor were marked as a repetition if the number of repetition was higher than five times. Having designed an experiment like this, Alcock et al., (2012) discusses that in these two languages under investigation, Kiswahili, children start using passives at earlier ages. In addition to that, there is no significant difference between these two languages in terms of the frequency of passives in child's speech. As pointed out by Demuth (1989), a high frequency in the input that a child receives is vital for the promotion of early productive use of the passive structures. When it comes to English, on the other hand, the extremely low frequency in English may be considered as the reason why passives appear in English late (Brown, 1973: 358). As cited in Alcock et al. (2012), some studies (Bencini and Valian, 2008; Brooks and Tomasello, 1999; Huttenlocher et al., 2002; Huttenlocher et al., 2004; Savage et al., 2003) show that English children also produce passives at an earlier age if the frequency of these structures is increased in the input in a laboratory setting, confirming that the frequency of passive constructions is attached a great deal of importance in the acquisition process. Compared to the studies which found out that actional passives are easier than non-actional passives, thus being acquired earlier, Alcock et al. (2012) found out that in both input and children's production, a significant proportion of passives are found not to be actional ones and authors explain this through the fact that the frequency of such constructions is high in these languages. Alcock et al. (2012) claims that structural requirements help by making frequency higher. They conclude by saying that "any maturational account of the production of passives cannot predict this; instead we must turn to frequency-dependent accounts"; however, as I mentioned in the previous section, frequency may facilitate maturation, thus creating a hypothesis "the higher the frequency of passive constructions is, the quicker A-chain matures". Here, one question remains unanswered, which is the role of overt morphology. Demuth et al. (2010) claims that morphology helps children a lot in their acquisition process unlike Alcock et al. (2012) which claims that overt structural properties do help by making the frequency of constructions higher, which makes children be exposed to the relevant structure more. In that sense, it would be very interesting to design an experiment in such a way that whether the effect of overt morphology (if there is an effect of overt morphological marking) overrides the effect of frequency can be tested in a language in which passives are not very frequent but there is morphologically overt marking of passive constructions. Only an experiment conducted on such a language can help us understand the effect of overt morphology. In that view, I speculate that morphological-marking helps children acquire the relevant structures because it gives children some clue, not creating an ambiguity between verbal and adjectival passives in English. 
Similarly, the paper (Kline \& Demuth, 2010) examines the factors that facilitate implicit learning by examining passive structures in Sesotho. Having taken two-year of work, Sesotho corpus consisting of 98 hours of spontaneous speech was created and was used to examine the passives for this study. To begin with, they draw attention to the fact that passive constructions are very frequent in the language and by comparing passives in English "as only $0.27 \%$ of the verbs these English speaking children heard were passives" (Kline and Demuth 2010) with passives in Sesotho because the percentage is $2.7 \%$. In the figure below, see the percentages of verbs used in passive constructions in Sesotho by both adults and children.

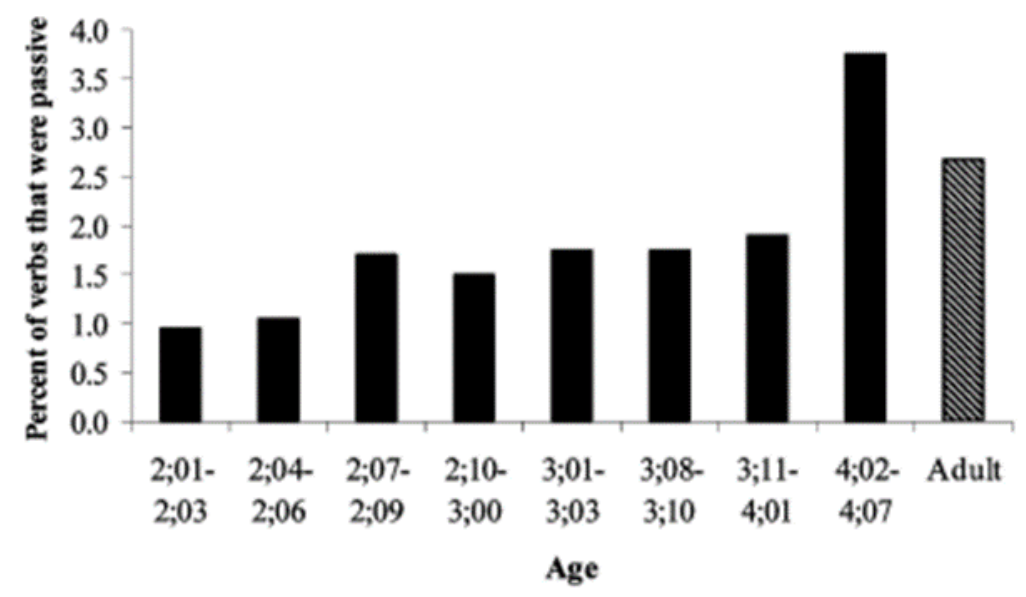

(Kline and Demuth 2010)

What is more interesting is that Sesotho-speaking children under the age of three construct sentences in the passive form more than English-speaking adults do. Furthermore, the authors pay attention to full passives and truncated passives, stating that $4 \%$ of the passive structures taken from Brown corpus of English child-directed speech have a by-phrase (Gordon and Chafetz 1990). However, this is not the case in Sesotho as $60 \%$ of passives in Sesotho corpus contain by-phrase, despite the lower utterance rate of passives by Sesotho-speaking children since $21 \%$ of their passives contain a by-phrase. At this point, I think that children do not want to utter sentences like "the mouse is being chased by a cat". Instead, they may prefer its active counterpart. Only when they do not want to mention the doer of the action, may they prefer using passive structure, which also results in the absence of by-phrase. In order to check whether this is really the case, the experimenters can design an experiment by giving some situations to Sesotho-speaking children and see whether they prefer using passives or actives in response to the experimental contexts. In doing so, the context-dependent differences in passive and active structures can be checked to explain why children prefer passives or actives to one another.

\subsection{Passives: A Challenging Task}

In this section, I review three papers stating that passives are difficult to acquire. To begin with, Hirsch et al. (2006) claims that A-chain Deficit Hypothesis cannot be right as children do not seem to have problems raising the subject from the edge of vP to the specifier position of a TP. However, following the ideas of Chomsky's Phase Impenetrability Condition (2001) which states that only the edge of the next lower phase is visible to the upper level and $\mathrm{vP}$ is not a strong phase, making passive structures grammatical, Wexler (2004) claims that this is not the case for children's immature grammar as they see all vP's and CP's as strong phases, which makes passives ungrammatical for children as "at the CP cycle, when Tense probes to check its phi-features, it may not access the DP in object position, since for the child, the intervening vP is a strong phase, and its complement (i.e. the VP) is invisible to syntactic operations at the higher CP phase due to PIC" (Wexler 2004). This also explains why children do not have problems raising the subject as it is generated at the specifier position of $\mathrm{vP}$; therefore, it is visible to the next phase, which makes movement operation possible. Having established that, Hirsch et al. (2006) designed an experiment by using a picture-matching task to test the conditions of passives, i.e. 
voice (active vs. passive), verb type (actional vs. non-actional) and passive length (long vs. truncated). They found out that children have problems with non-actional passives. In addition to that, they also had adult participants to test whether there is something inherent in non-actional verbs that interacts with voice, which may be the reason of this difficulty. However, they found out that this was not the case as adults performed well on both actional and non-actional passives. In order to explain this, the authors distinguish stative passives (the door is open) and resultative passives (the tank is filled) based on Embick's analysis (2004), which claims that such a distinction should be made taking into consideration the fact that resultative passives entail events while stative passives do not. Among many other tests to differentiate these two types of adjectival passives, there is one which states that only resultative passives can be used with manner adverbials as they entail events as shown below:

The Carefully filled tank

*The Carefully full tanked

(Hirsch et al. 2006: 9)

The ungrammaticality of the second DP is that it is a stative passive, which does not entail an event, therefore it cannot be used with a manner adverb. Taking this distinction into account, the authors claim that actional passives are easier to acquire because they have resultative interpretation unlike nonactional passives. Furthermore, verbal passives and resultative passives seem to be parallel in terms of meaning, however resultative passive (type of adjectival passive) does not undergo movement unlike the verbal one. This resultative analysis does not cause a problem for UPR as the subject is generated in the spec. position of $\mathrm{vP}$, therefore it is accessible for movement. On the contrary to what Hirsch et al. (2006) claim, Messenger et al. (2012) believes that there are no differences between actional passives and nonactional passives despite the early findings showing that there is indeed a difference. The authors claim that the difference found in earlier studies is not because of the lack of children's abstract syntactic representations of passive structures but because of the experimental designs. In order to show this, they carried out three different experiments using a priming task (whether children will be able to produce a passive sentence after hearing a passive prima from the experimenter) to compare actional passives with non-actional passives. To begin with the results of the first experiment, they showed that irrespective of verbs types, whether it is an actional verb or a non-actional verb, children produce more sentences that are passive after hearing a passive prime. The same result was for the adults, who were part of this experiment as a control group, too. Based on this result, authors claim that children can extract the necessary pieces of information so as to create an abstract representation of passives based on the prime they hear as well as being able to use this representation for producing a passive sentence. In the second experiment, authors compare experiencer-theme passives with theme-experiencer passives by using passive constructions in present progressive form in order not to have so-called adjectival passives . They found out that unlike the previous studies, children did not have problems with experiencer-theme verbs. The experiment three was conducted by using a traditional picture-matching task, which had been used in previous studies to show that children had difficulty comprehending experiencer-theme passives. They used this method in order to show that the results of earlier experiments were due to experimental design. They found out that the successful children who were able to produce both actional and nonactional passives in the first two experiments failed to do so in the experiment three, which authors claim is due to the experimental design. Therefore, they conclude that children who are 3 or 4 years old have mental representation of passive, which is not semantically constrained to a certain class of verbs and are able to produce sentences in passive construction irrespective of verb types unlike the previous studies. The authors believe that the previous results reflect an artifact of the task used. In my opinion, although the authors sound convincing in that experimental design is crucial, the previous results, which are in contradiction with what has been found in Messenger et al. (2012), cannot be simply due to experimental design. In addition to that, the authors use priming task and although they say they children do not seem to simply copy the structure they use, there is still a possibility that they can do something like this, which may reduce the validity of the experiments. To be more precise, what I mean is that the input must be more restricted to make sure that children create an abstract representation based on the input rather than copying the input. Besides, rather than simply saying the previous results are due to experimental design, there must be something else in accounting for why children who are good at priming tasks are bad at sentence-matching task as the latter may require children to access to syntax, semantics and world 
knowledge (as cat is never chased by a mouse) as movement and thematic roles are involved and also non-linguistic elements such as being able to describe a picture.

Huang et al. (2013) compares four accounts that provide different explanations as to why passives in English are acquired late. The first two accounts are syntactic account and frequency account, each of which was discussed in the previous section. The third account is that it is claimed that children do not have access to strong and unambiguous cues to the passive constructions in their language, which authors call as a cue-based account. (Bates \& MacWhinney 1987; 1989). The final account is the Incremental Processing Hypothesis, which states that "the interpretation of passives is difficult when it requires children to revise an earlier commitment to a role assignment" (Trueswell and Gleitman 2004). To give more details about the last account, it is worth mentioning the Garden-Path effect (Bever 1970), as illustrated below:

a. The boat floated down the river.

b. The boat floated down the river sank.

Both of the sentences are perfectly grammatical despite the latter being perceived as ungrammatical by the native speakers at first sight as it requires reinterpretation of the reduced relative clause, floated, which is generally interpreted as the main verb till the speaker/hearer hears/sees the second verb, the main verb, in the structure linearly.

In the light of these four accounts, the authors design an experiment to see which account holds for explaining the late acquisition of passives. Before giving the details of the experiment, noun-noun-verb (dubbed as NNV) constructions in Mandarin should be explained because the experiment is based on these two structures. In Mandarin, the syntactic marker-BA shows that the preceding noun is an agent, whereas, the syntactic marker -BEI indicates that the preceding noun is a theme as shown below:

\begin{tabular}{|c|c|c|c|c|}
\hline Seal & BA & fish & quickly & eat \\
\hline & 把 & 小鱼 & 很快就 & 吃掉了 \\
\hline \multicolumn{5}{|c|}{ The seal is quickly eating the fish } \\
\hline $\begin{array}{l}\text { Seal } \\
\text { 海豹 }\end{array}$ & $\begin{array}{l}\text { BEI } \\
\text { 被 }\end{array}$ & $\begin{array}{l}\text { sharl } \\
\text { 婆魚 }\end{array}$ & $\begin{array}{l}\text { quickly } \\
\text { 很快就 }\end{array}$ & $\begin{array}{l}\text { eat } \\
\text { 吃掉了 }\end{array}$ \\
\hline
\end{tabular}

(Huang et al. 2013)

-BA in the first sentence shows that seal is the agent and -BEI in the second sentence shows that seal is the theme of the sentence, which is interesting in terms of passives because English-speaking children who have problems with passives may not be able to assign thematic roles easily, which in turn results in this problem. Conducting an eye-movement experiment, authors show that adults rapidly make use of morphsyntactic cues (-BA and -BEI) to assign thematic roles in the structure. However, they had some problems with -BEI when they previously assigned a different thematic role (agent to the first noun although -BEI dictates that it should be a theme), which is predicted by Incremental Processing Hypothesis. The same experiment is conducted with children and the results show that similarly children are better at interpreting passives in Mandarin when they see the passive morpheme before the assignment of the thematic role, which requires a change in the assignment of a thematic role, and this change is what makes passive more difficult, which is in line with Incremental Processing Hypothesis, which claims that passives are difficult because children have to change the thematic roles that are already assigned.

\subsection{Analysis of Passives: Semantics \& Pragmatics}

As presented in the previous sections, some counter arguments and different ways of explanation in the literature exist. However, not many things are said about the meaning of passive structures. In this section, I briefly discuss the semantics and pragmatics of passives, which may be the reason of difficulty. Starting with the quantifier-scope preference when the voice of the sentence changes, let us consider the following examples in English. 


\section{a. Someone loves everyone.}

b. Everyone is loved by someone.

Both sentences, one in active and one in passive, exhibit both quantifier-scope readings:

a. $\exists x \forall y($ love $y x)$

b. $\forall \mathrm{y} \exists \mathrm{x}($ love $\mathrm{y} \mathrm{x})$

However, the semantic preference for the active sentence is the interpretation in (a), while, for the passive sentence, it is (b), which shows that passive structure clearly interacts with semantics and pragmatics. However, in the literature, there is not clear mention of semantic interpretation and pragmatics, which should also be taken into consideration. To start with pragmatics, one should answer the question of "why do people use passives?". One of the common use of it is to shift the focus from the agent to the patient. Then, the question is why children need to shift the focus in the early stages of acquisition or at what age children are able to arrange the discourse (CP-level syntax) to convey focus or topic. One of the arguments for the presence of vP layer in syntax is that children use sentences like "daddy eat cookies", which does not have tense, and the child, who utters a sentence like this, seems to have built up his/her syntax up to the vP layer. Therefore, if we assume that the order of acquisition is VP- vP- TP - CP like syntax operating bottom-up, and passives are more related to CP level "arrangements", then this would explain the late acquisition of passives. In order to test this, an experiment can be designed in such a way that the acquisition of one of the other structures that are related to CP domain is tested in English. Then, if the acquisition of that particular structure is parallel to the acquisition of passives in terms of onset of acquisition, then we would have a valid argument, explaining the late acquisition. Besides, when we recall the experiment conducted on Bantu languages, it was the case that passive use is dictated in some structures and interesting enough, these languages exhibit very strong tendency to put the topic in the subject position, thereby, being called topic-oriented languages. Combining the frequency account with my topic account, I claim that passives are operations, whose effects are beyond VoiceP as they arrange the discourse as well. Second, actional passives are acquired earlier than non-actional passives. This may be related to the other cognitive domains as children are said to be egocentric and love to comment on their immediate environments. Keeping that in mind, Von Fintel \& Heim (2011) claims that "the intension of a sentence can be applied to any world and give the truth-value of the sentence in that world.", which shows the existence of multiple worlds. Besides, It is known that verbs like believe, know, create intensional contexts by bringing intensional operators, whose interpretation depends on the world according to which, the sentence is interpreted as illustrated below:

$\left[[\right.$ believe] $] \mathrm{w}(\mathrm{x})=\lambda \mathrm{p}$. For all $\mathrm{w}^{\prime} \in \mathrm{W}$ such that $\mathrm{w}$ is compatible with $\mathrm{X}^{\prime}$ 's beliefs in $\mathrm{w}, \mathrm{p}\left(\mathrm{w}^{\prime}\right)=1$

[[Gary believed that John saw a unicorn] $] \mathrm{w}=1$ iff for all $\mathrm{w}^{\prime} \in \mathrm{W}$ such that $\mathrm{w}^{\prime}$ is compatible with Gary's

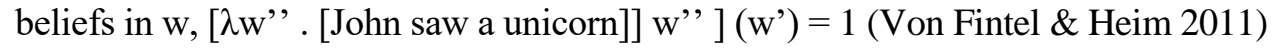

Based on this theoretical account, the predicates, believe, know, assume etc., which are also non-actional verbs, seem to be more complex to be interpreted. Recalling the desire of children to talk about their immediate environments, in semantic terms, it is the actual world, I believe that the source of difficulty with non-actional verbs are also due to the fact that their semantics is more complex. In addition to that, world knowledge is to be taken into account as well since when a child sees a sentence like "the cat is being chased by the mouse", s/he can interpret this sentence in such a way that the cat is the agent due to the (actual) world knowledge as s/he may have problems accessing to the other possible worlds.

\section{CONCLUSION}

In this paper, the careful review of literature was conducted and found out that there are some counter arguments in terms of the reasons why passives are more difficult or why some certain types of passives (non-actional to be more precise) are difficult. Although authors provide different explanations in relation to the nature of passives, there is not much of an agreement reached. Having reviewed the literature, I conclude that early acquisition of passives in certain languages like Bantu languages cannot 
result solely from frequency even though frequency makes the process faster. Having established that, there are two accounts to consider, which are the syntactic account (Wexler, 2004) and Incremental Processing Hypothesis (Trueswell \& Gleitman, 2004). (Huang et al., 2013), who favor Incremental Processing Hypothesis, do not make a comment on Wexler's syntactic hypothesis, which states that children regard all vP's and CP's as strong phases, which makes passives ungrammatical for them, even though Huang et al. (2013) reject A-chain Deficit Hypothesis, which has already been rejected by Wexler's syntactic account. To conclude, there must be more studies in term of whether syntactic account or incremental processing hypothesis is right in prediction of passive structures. However, in either way (syntax or incremental processing), frequency plays a role in boosting the acquisition process by either making children be faster at reassigning thematic roles, which is the source of difficulty according to incremental processing hypothesis, or making children be aware of the fact that vPs are not strong phases, thereby making passives grammatical, so that children can use them. Finally, I propose that semantics and pragmatics play a role in the acquisition of passives as well following the intensional semantics model.

\section{REFERENCES}

Alcock, K. J., Rimba, K., \& Newton, C. R. (2012). Early production of the passive in two Eastern Bantu languages. First Language, 32(4), 459-478.

Allen, S., Crago M. (1996). Early passive acquisition in Inuktitut. Journal of Child Language. 23(1), $129-155$.

Bates, E., \& MacWhinney, B. (1989). Functionalism and the competition model. The Crosslinguistic Study of Sentence Processing, 3, 73-112.

Bates, E., MacWhinney, B., \& MacWhinney, B. (1987). Competition, variation, and language learning. Mechanisms of Language Acquisition, 157-193.

Bencini, G. M. L., Valian V. (2008). Abstract sentence representation in 3-year-olds: Evidence from comprehension and production. Journal of Memory and Language 59, 97-133.

Borer, H., Wexler K. (1987). The maturation of syntax. (eds. In Thomas Roeper \& Edwin Williams), Parameter Setting and Language Acquisition, 123-172. Dordrecht: Reidel.

Borer, H., Wexler K. (1992). Bi-unique relations and the maturation of grammatical principles. Natural Language and Linguistic Theory 10, 147-189.

Bresnan, J., Mchombo, S. (1987). Topic, pronoun, and agreement in Chichewa. Language 63, 741-782.

Brooks, P. \& Tomasello, M. 1999. Young children learn to produce passives with nonce Developmental Psychology, 35(1), 29-44.

verbs.

Chomsky, N. (2001). Derivation by Phase. In M. Kenstowicz (ed.) Ken Hale: A life in language, 1-

52. Cambridge: MIT Press.

Demuth, K. (1989). Maturation and the acquisition of the Sesotho passive. Language 65(1), 56-80.

Embick, D. (2004). On the Structure of Resultative Participles in English. Linguistic Inquiry 35(3), 355392.

Fox, D., Grodzinsky, Y. (1998). Children's passives: A view from the by-phrase. Linguistic Inquiry, 29(2), 311-332.

Gordon, P., Chafetz, J. (1990). Verb-based versus class-based accounts of actionality effects in children's comprehension of passives. Cognition, 36(3), 227-254. 
Hirsch, C., Wexler, K. (2006). Children's passives and their resulting interpretation. In The proceedings of the inaugural conference on generative approaches to language acquisition-North America, University of Connecticut Occasional Papers in Linguistics, 4, 125-136.

Huang, Y. T., Zheng, X., Meng, X., Snedeker, J. (2013). Children's assignment of grammatical roles in the online processing of Mandarin passive sentences. Journal of Memory and Language, 69(4), 589-606.

Huttenlocher, J., Vasilyeva, M., Cymerman, E., Levine, S. (2002). Language input and child syntax. Cognitive Psychology, 45(3), 337.

Huttenlocher, J., Vasilyeva M., Shimpi P. (2004). Syntactic priming in young children. Journal of Memory and Language, 50, 182-195.

Kline, M., Demuth, K. (2010). Factors facilitating implicit learning: The case of the Sesotho passive. Language acquisition, 17(4), 220-234.

Messenger, K., Branigan, H. P., McLean, J. F., Sorace, A. (2012). Is young children's passive syntax semantically constrained? Evidence from syntactic priming. Journal of Memory and Language, 66(4), 568-587.

Savage, C., Lieven, E., Theakston, A., Tomasello, M. (2003). Testing the abstractness of children's linguistic representations: Lexical and structural priming of syntactic constructions in young children. Developmental Science, 6(5),557.

Stromswold, K. (1996). Does the VP-internal subject stage really exist? Paper presented at the 21st Annual Boston University Conference on Language Development.

Trueswell, J., Gleitman, L. (2004). Children's eye movements during listening: Developmental evidence for a constraint-based theory of sentence processing. In J. M. Henderson \& F. Ferreira (Eds.), The interface of language, vision, and action: Eye movements and the visual world, (pp. 319-346). New York, NY, US: Psychology Press.

Wexler, K. (2004). Theory of Phasal Development: Perfection in Child Grammar. MIT Working Papers in Linguistics, 48, 159-209. 